\title{
32. DATA REPORT: HYDRAULIC CONDUCTIVITY MEASUREMENTS ON DISCRETE SAMPLES COLLECTED FROM LEG 141, SITE $863^{1}$
}

\author{
Kevin M. Brown ${ }^{2}$
}

\begin{abstract}
Measurements made on samples collected across a prominent zone of cementation occurring at depths below $\sim 400 \mathrm{mbsf}$ at Site 863 suggest that this zone is associated with a 100 fold reduction in hydraulic conductivity. The cements are related to significant smectite and zeolite deposition and cause sharp changes in sonic velocity, porosity, and thermal conductivity. The current pore fluid chemistry profile suggests cementation is continuing in-situ at the present time.
\end{abstract}

\section{INTRODUCTION}

Site 863 lies directly above the Chile Triple Junction and is unique in terms of its tectonic, hydrogeologic and diagenetic history (Brown et al., this volume). Visible evidence for the association of diagenetic, structural, and hydrogeologic processes is first observed at shallow levels at this site in the form of the black sulfide-rich mineralizedfractures most prominent in a complexly deformed region between 3.3 to 42 mbsf (see "Site 883" chapter in Behrmann, Lewis, Musgrave, et al., 1992). This sulfide-rich region is also spatially associated with warm temperature anomalies $\left(3^{\circ} \mathrm{C}\right.$ warmer than ambient) located at $30 \mathrm{mbsf} \pm 10 \mathrm{~m}$ and perhaps at $70 \mathrm{mbsf} \pm 10 \mathrm{~m}$.

Deeper in the section at Site 863, a complex cementation zone has developed in sediments of late Pleistocene age. Limited cementation begins to be observed in the subvertically bedded sediments below $\sim 250$ mbsf (Kurnosov, this volume; Prior, this volume). The first physical property evidence for the onset of cementation is the relatively large increase in seismic velocity between $\sim 280$ and $350 \mathrm{mbsf}$ (Brown et al., this volume). The upper boundary of the region of greatly enhanced cementation occurs at $400 \mathrm{mbsf}$. This zone is associated with a relatively rapid downward decrease in porosity of $10 \%$ between $\sim 390$ and 430 mbsf and an abrupt increase in thermal conductivity (Fig. 1). Core scale, thin section, and scanning electron microscope (SEM) observations indicate that carbonate cements sporadically occur below $200 \mathrm{mbsf}$, with limited clay cementation below $250 \mathrm{mbsf}$ (Prior et al., this volume). The main cementation front that is developed at $\sim 400 \mathrm{mbsf}$ is related to the deposition of smectitic clays and $\mathrm{K}$ and Ca zeolites (Fig. 1; Kurnosov et al., in press; Prior et al., in press). The authigenic smectitic clays (Fig. 1) in the cementation zone at Site 863 occur as pore filling phases; in some instances as thin filaments that fringe the grains. In other areas, they are sufficiently abundant to almost occlude the pore spaces (Prior et al., this volume). While early clay cementation appears to predate the zeolites, clay and zeolite cementation have continued synchronously for a time. Carbonate cements are also observed at this site, predominantly occurring as late stage pore- and fracture-filling phases. Where they occur together, SEM observations indicate the carbonate post dates any clay mineral and zeolite cements (Prior et al., this volume). Where developed, early clay minerals and zeolites also appear to restrict the occurrence of the later carbonates.

Hydraulic conductivity measurements were made on discrete samples collected from the near-vertical section consisting of cemented interbedded silty-muddy turbidite sands and silty muds between $\sim 400$

'Lewis, S.D., Behrmann, J.H., Musgrave, R.J., and Cande, S.C. (Eds.), 1995. Proc. ODP, Sci. Results, 141: College Station, TX (Ocean Drilling Program).

Scripps Institution of Oceanography, University of California at San Diego, La Jolla, CA 92093-0220, U.S.A. to $700 \mathrm{mbsf}$. Increasing degrees of cementation in this interval allowed the paleo-magnetic drill to be used to collect a series of good quality $2.54 \mathrm{~cm}$ diameter cylindrical samples from the split half-core. The data illustrate the interaction between diagenesis and the hydraulic conductivity structure in the section beneath the cementation front at $\sim 400$ mbsf.

\section{EXPERIMENTAL APPARATUS AND PROCEDURE}

The basic features of the constant flow-rate permeameter used to determine the hydraulic conductivities of core samples collected from Site 863 are shown in Figure 2. Prior to the measurements being made the samples were kept moist in sealed containers and stored at $4^{\circ} \mathrm{C}$. The ends of the cylindrical hydraulic conductivity samples were cut to the required length and their dimensions are determined prior to being placed in the confining chamber (sample dimensions were approximately $2.54 \mathrm{~cm}$ in diameter and 1 to $1.5 \mathrm{~cm}$ long). The samples were placed between the upper and lower titanium (selected for its corrosion resistance) platens and an impermeable flexible polyurethane jacket was cast around the whole sample assembly to isolate the sample from the fluid producing the confining pressure. The sample assembly allows fluids to be pumped along the axis of the sample via ports and inert porous plastic plates at the top and base of the sample assembly. To alleviate problems associated with corrosion in the presence of the artificial saline pore fluid all tubing in the system was replaced with PEEK plastic.

The sample assembly was then placed in the confining chamber and the external system pressurized. To force any remaining air into solution, previously de-aired artificial pore fluid was introduced into the internal system and sample, and the system was subsequently back pressured to $0.34 \mathrm{MPa}$. The major cation composition of the artificial pore fluid was made to correspond to the in-situ values at a particular sample's depth. The fluid compositions used in these measurements correspond to those determined from pore fluids extracted from the cores onboard ship ("Site 863" chapter in Behrmann, Lewis, Musgrave, et al., 1992). Particular attention was paid to the $\mathrm{Na}, \mathrm{Mg}$, $\mathrm{Ca}$, and $\mathrm{K}$ concentrations and the $\mathrm{pH}$, the other cations occurred in very small quantities were ignored for the purposes of these tests.

Hydraulic conductivity determinations were commonly attempted at more than one flow rate and effective confining pressure to ascertain how stable the system was and to assess if hydraulic conductivities changed significantly with effective stress. A constant flow rate was maintained during the hydraulic conductivity tests with a variable speed syringe pump, manufactured by Harvard Apparatus, USA. Flow rates are considered to be accurate to $\pm 0.5 \%$ at the mid range, and $\pm 2 \%$ at the lowest range. The flow pump technique has several advantages over the standard constant head and falling head methods of permeability measurement, the most important being the ease with 
Figure 1. Summary of some of the physical property and mineralogic data that illustrate the nature of the cementation front developed below $\sim 400 \mathrm{mbsf}$. A. Porosity (Behrmann, Lewis, Musgrave, et al., 1992). B. Thermal conductivity. C. Smectite content of the 0.001 to $0.01 \mathrm{~mm}$ fraction (Kurnosov et al., in press; Prior et al., in press).
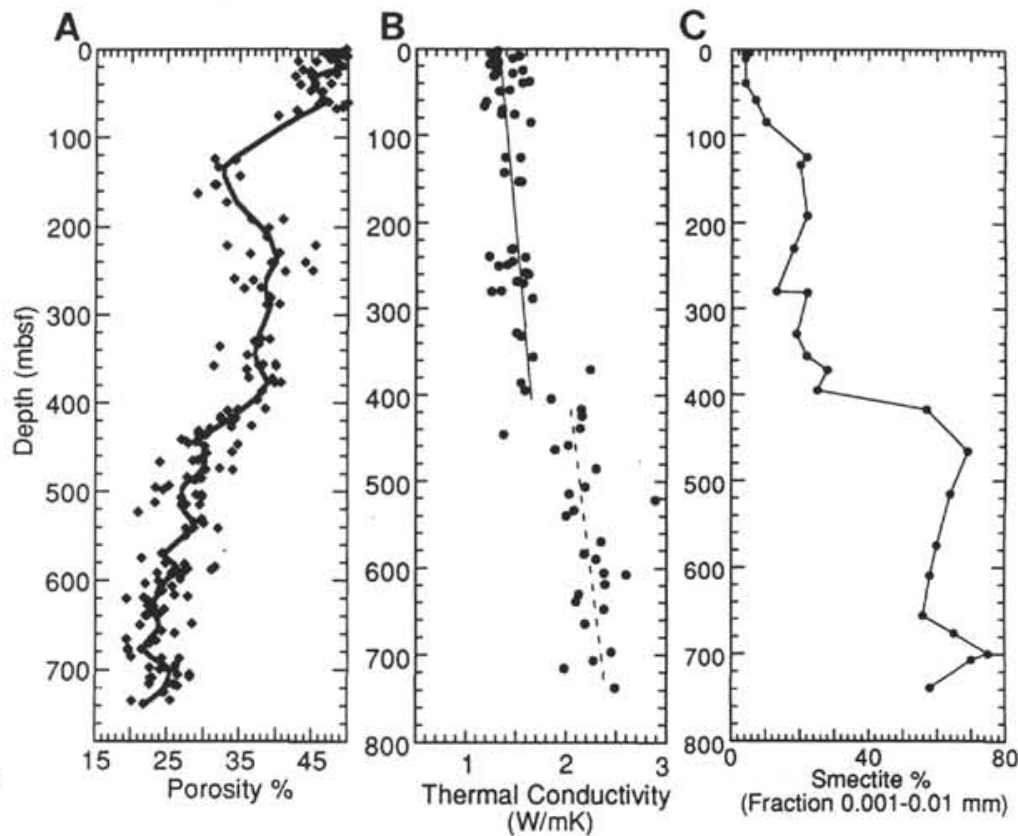

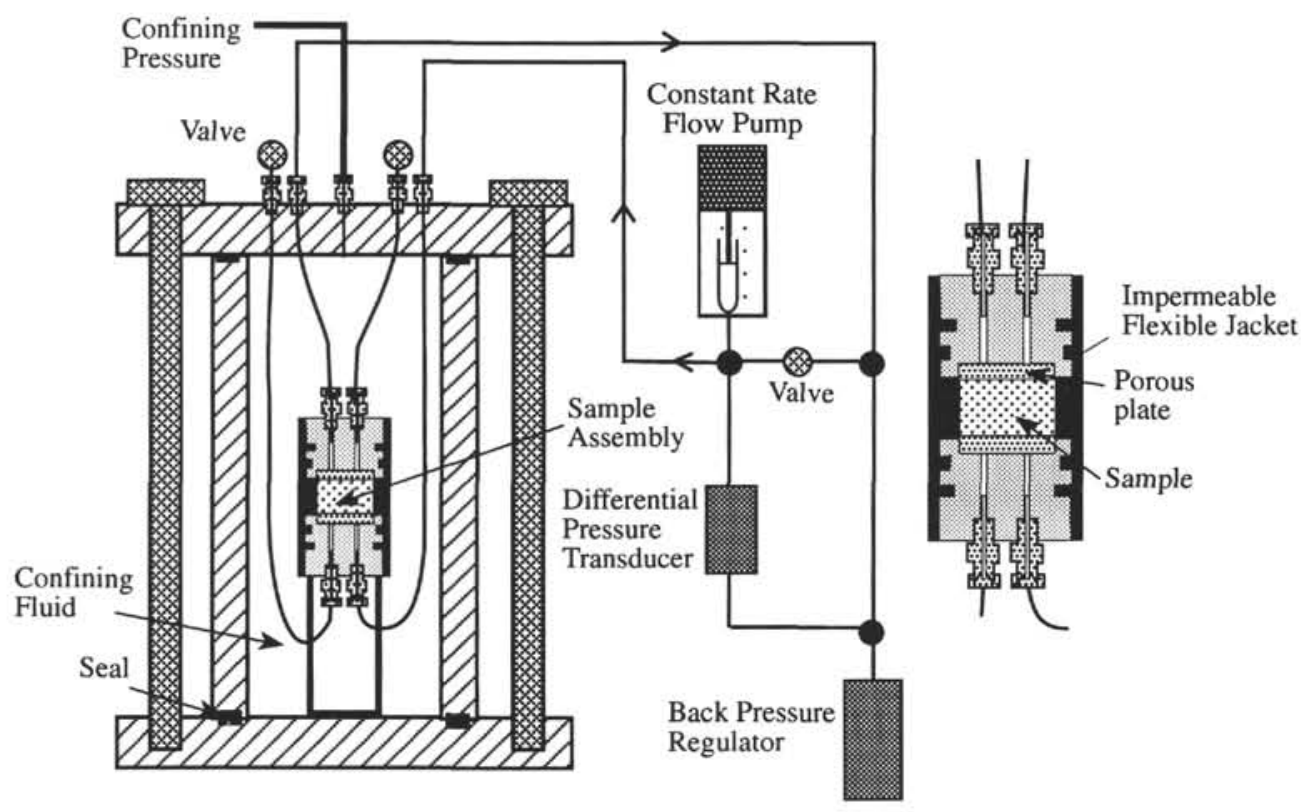

Figure 2. Schematic diagram of the confining cell and constant rate permeameter used in this study.

which very low flow rates (and hence low hydraulic gradients) can be reliably maintained (Olsen et al., 1988; Olsen et al., 1985; Olson and Daniel, 1981; Pane et al., 1983). By changing the volume of the syringe and the rate of displacement, the rate at which the permeant is passed through the sample can be varied from $8.5 \times 10^{-2} \mathrm{ml} \mathrm{s}^{-1}$ to $1 \times 10^{-8} \mathrm{ml} \mathrm{s}^{-1}$. In all tests, the flow rate was chosen so that the excess pore pressure generated was $<10 \%-15 \%$ of the average vertical effective stress. This was done in order to minimize sample disturbance caused by seepage-induced consolidation (Pane et al., 1983; Olsen et al., 1985). The out flow side of the sample was kept at a constant fluid back-pressure (Fig. 2). Characteristically, the differential pressure across the sample during a flow-pump test would increase from zero to a maximum constant value when a steady-state pressure gradient was established. The hydraulic conductivity was then calculated using the sample's dimensions, Darcy's law, and the steady state head difference (Freeze and Cherry, 1979) across the sample:

$$
K=\frac{q}{A}\left(\frac{d h}{d l}\right)^{-1},
$$

where $q$ is the volumetric flow rate, $A$ is the cross sectional area of the sample normal to the direction of flow and $d h / d l$ is the steady state head gradient across the sample $\left(d h=\Delta P / g \rho_{w}\right.$, where $\Delta P$ is the differential pressure across the sample, $g$ is the acceleration due to gravity, and $\rho_{w}$ is the density of water).

\section{RESULTS AND DISCUSSION}

The results of hydraulic conductivity determinations are shown in Figure 3 . These data are from the poorly sorted turbidite sands which contain variable amounts of fine silt and clay. For these units the determined hydraulic conductivity values generally fall between $10^{-8}$ 
and $3 \times 10^{-11} \mathrm{~cm}^{-1}$. These values are low; rather more characteristic of marine clays and muds than cleaner sandstones (which commonly have hydraulic conductivities of the order of $10^{-5}$ to $10^{-1} \mathrm{~cm}^{-1}$; see for example Freeze and Cherry, 1979). There is also a trend towards increasing hydraulic conductivity values with depth below $\sim 500 \mathrm{mbsf}$. The hydraulic conductivity increases by approximately two orders of magnitude from the lowest hydraulic conductivity zone $(\sim 400-500$ mbsf) and the base of the hole at $750 \mathrm{mbsf}$.

The presence of veins suggests the fluid pressure may be elevated with respect to a hydrostatic gradient. There were, however, no measurements of the in-situ pore fluid pressures at this site and, as a consequence, there are limited constraints as to how the effective overburden pressure may change with depth. Fortunately, little change in hydraulic conductivity was observed when the effective confining pressure was varied on the samples. This apparent rigidity is probably due to the significant cementation of the samples. For example, there is very little offset between the 2 and $5 \mathrm{MPa}$ effective confining pressure curves (Fig. 3). Thus, it is not expected that in-situ values would vary from the laboratory values by more than a factor of two to three.

Geochemical analysis of the current pore fluids in the section at this site shows that between 400 and 500 mbsf there is currently a zone of generally strongly reduced salinities (Fig. 4) associated with large discordances in the $\mathrm{B}, \mathrm{F}, \mathrm{Li}, \mathrm{Sr}, \mathrm{Ca}, \mathrm{Mg}, \mathrm{K}, \mathrm{Si}$ profiles ("Site 863" in Behrmann, Lewis, Musgrave, et al., 1992; Brown et al., this volume). Low salinities have, in the past, been associated with freshening caused by the input of pure water derived from the smectite to illite reaction occurring at depth within accretionary wedges like the Barbados wedge (Gieskes et al., 1990a, b; Vrolijk et al., 1991). The presence of the freshened fluids could be taken to suggest lateral flow at this level involving fluid migrating from greater depths because this diagenetic reaction occurs between $80^{\circ}$ and $120^{\circ} \mathrm{C}$ (Bruce, 1984 ; Perry and Hower, 1972) and formation temperatures in the 400 to 450 mbsf region at Site 863 are only between $40^{\circ}$ and $50^{\circ} \mathrm{C}$ (Sawyer et al., this volume). There is, however, no accompanying negative anomaly in the more chemically conservative chloride component (Fig. 4). Instead, the chloride concentrations increase across this interval. This "freshened zone" is, thus, proposed to be a very diagenetically active area, with ongoing cementation having removed some active ionic species but not the more conservative chloride component (Brown et al., this volume).

The generally low hydraulic conductivities of this section relate, in part, to the poorly sorted nature and presence of detrital clay in these turbidite sandstones. Variable, but generally significant, amounts of cementation by authigenic calcite, zeolite, and clays have, however, also been observed in these sandstones (Prior et al., this volume). The zone with the lowest hydraulic conductivities is spatially related to the main cementation front (Fig. 1), lying between 400 and $470 \mathrm{mbsf}$, and the zone of freshened fluids (Figs. 4 and 5). If the latter is truly the product of ongoing cementation, it seems reasonable that the zone with the lowest hydraulic conductivity is spatially coincident with this "freshened" region (Fig. 5). The smectite content (Fig. 1) of the section also generally decreases downward, apart from a sharp peak located around $700 \mathrm{mbsf}$, from a maximum of $70 \%$ at $~ 460 \mathrm{mbsf}$ to $57 \%$ at $750 \mathrm{mbsf}$. The progressive increase in hydraulic conductivity below 450 to 500 mbsf would then be consistent with these other indications that cementation gradually decreases with depth below $\sim 500 \mathrm{mbsf}$.

\section{SUMMARY}

In summary, it appears that Site 863 is a prime example of a complex hydrogeologic system in which fluid flow, physical properties, and geochemical processes are all interacting closely. Hydraulic conductivity measurements have been made on samples collected across a prominent cementation zone developed at depths below $\sim 400$ mbsf. This cementation zone is associated with the onset of significant smectite and zeolite precipitation and sharp changes in sonic velocity, porosity, and thermal conductivity. The current pore fluid

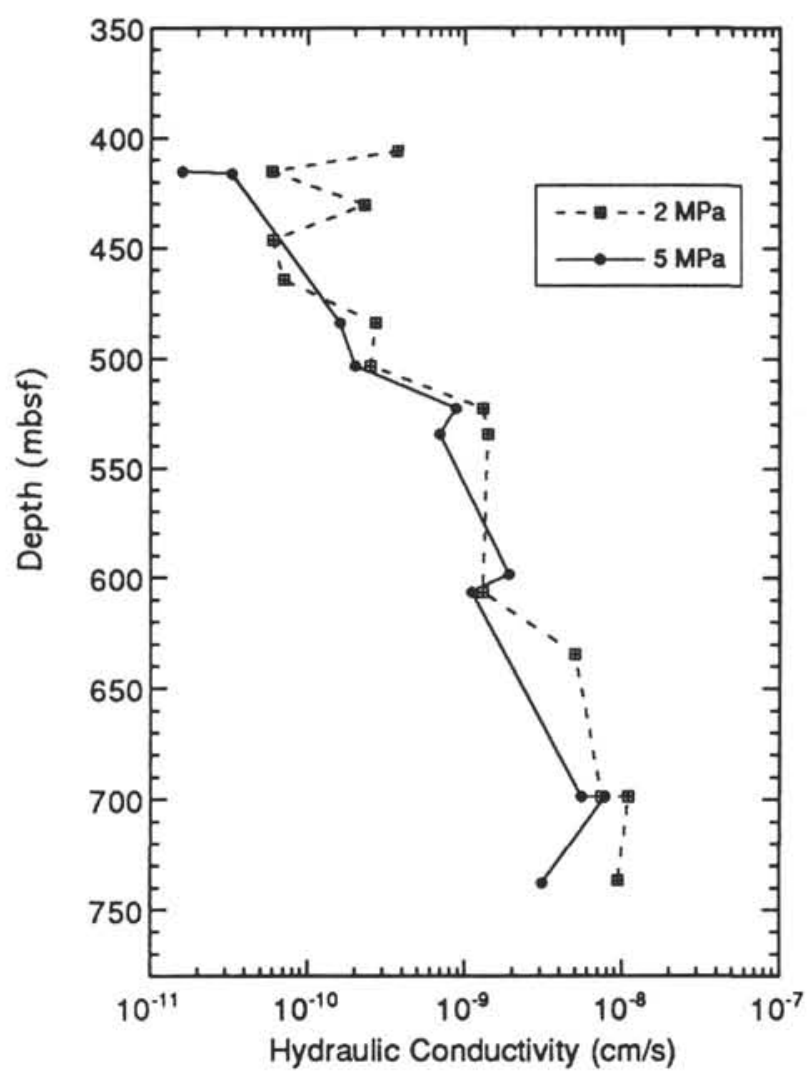

Figure 3. Hydraulic conductivity vs. depth at Site 863 . Determinations at effective confining pressures of 2 and $5 \mathrm{MPa}$ are presented.

chemistry profile suggests the most cementation is continuing at the present time in the section between 400 and $500 \mathrm{mbsf}$. The hydraulic conductivity data suggest that the cementation zone is characterized by generally very low hydraulic conductivities, with values ranging from $10^{-11}$ to $10^{-8} \mathrm{~cm}^{-1}$. In detail, the lowest hydraulic conductivities $\left(\sim 10^{-11} \mathrm{~cm}^{-1}\right)$ occur in the upper part of the cemented region, between 400 to 500 mbsf, with a 100 fold increase in hydraulic conductivity down to the base of the hole.

\section{ACKNOWLEDGMENTS}

The author would like to thank Homa Lee for his helpful comments on this data report and the shipboard scientific party, technicians, and crew on Leg 141 for a productive and enjoyable cruise. This work was supported by USSAC Grant 141-20689.

\section{REFERENCES $*$}

Behrmann, J.H., Lewis, S.D., Musgrave, R.J., et al., 1992. Proc. ODP, Init. Repts., 141: College Station, TX (Ocean Drilling Program).

Bruce, C.H., 1984. Smectite dehydration-its relation to structural development and hydrocarbon accumulation in northern Gulf of Mexico basin. AAPG Bull. 68:673-683.

Freeze, R.A., and Cherry, J.A., 1979. Groundwater: Englewood Cliffs, NJ (Prentice-Hall).

Gieskes, J.M., Blanc, G., Vrolijk, P., Elderfield, H., and Barnes, R., 1990a. Interstitial water chemistry-major constituents. In Moore, J.C., Mascle, A., et al., Proc. ODP, Sci. Results, 110: College Station, TX (Ocean Drilling Program), 155-178.

"Abbreviations for names of organizations and publications in ODP reference lists follow the style given in Chemical Abstracts Service Source Index (published by American Chemical Society). 
Gieskes, J.M., Vrolijk, P., and Blanc, G., 1990b. Hydrogeochemistry of the Northern Barbados Accretionary Complex Transect: ODP Leg 110. J. Geophys. Res., 95:8809-8818.

Olsen, H.W., Morin, R.H., and Nichols, R.W., 1988. Flow pump applications in triaxial testing. In Donaghe, R.T., Chaney, R.C., and Silver, M.L. (Eds.), Advanced Triaxial Testing of Soil and Rock. ASTM Spec. Tech. Publ., 977:68-81.

Olsen, H.W., Nichols, R.W., and Rice, T.L., 1985. Low gradient permeability measurements in a triaxial system. Geotechnique, 35:145-157.

Olson, R.E., and Daniel, D.E., 1981. Measurement of the hydraulic conductivity of fine-grained soils. In Zimmie, T.F., and Riggs, C.O. (Eds.), Permeability and Groundwater Contaminant Transport. ASTM Spec. Tech. Publ., 746:18-64.
Pane, V., Croce, P., Znidarcic, D., Ko, H.-Y., Olsen, H.W., and Schiffman, R.L. 1983. Effects of consolidation on permeability measurements for soft clay. Geotechnique, 33:67-72.

Perry, E.A., and Hower, J., 1972. Late-stage dehydration in deeply buried pelitic sediments. AAPG Bull., 56:2013-2021.

Vrolijk, P., Fisher, A., and Gieskes, J., 1991. Geochemical and geothermal evidence for fluid migration in the Barbados accretionary prism (ODP Leg 110). Geophys. Res. Lett., 18:947-950.

Date of initial receipt: 30 September 1993

Date of acceptance: 4 October 1994

Ms 141SR-039 

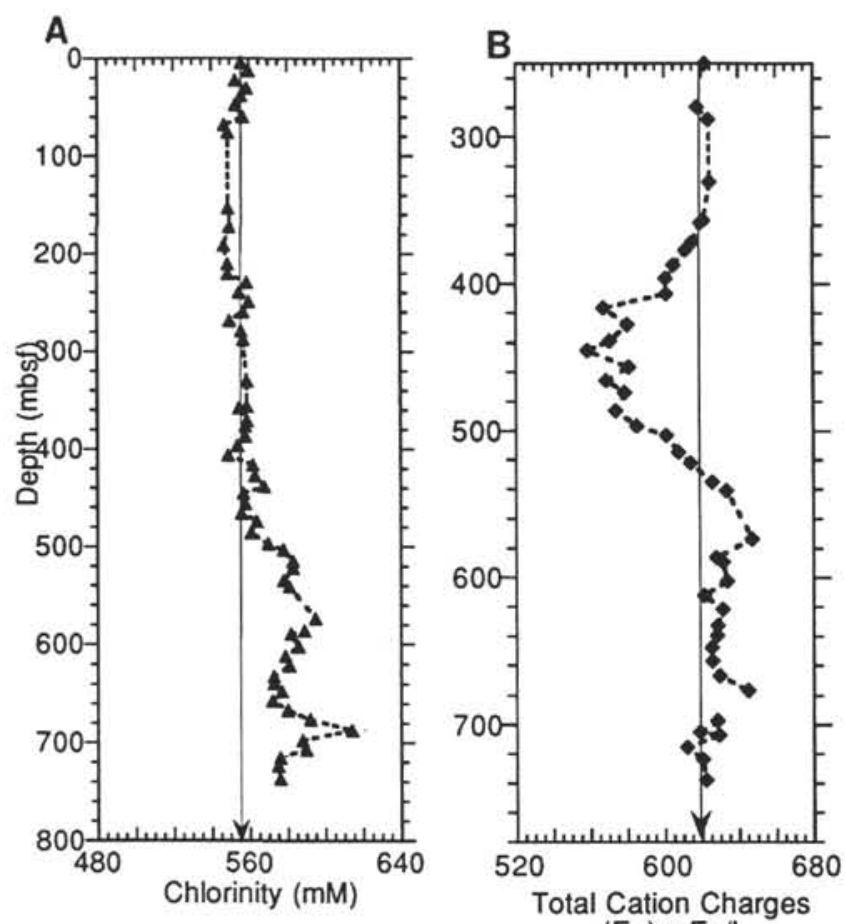

Figure 4. Synthesis of the pore fluid down hole profiles showing variations in (A) chlorinity and (B) total dissolved cation charge (data from "Site 863" in Total Cation Charge Behrmann, Lewis, Musgrave, et al., 1992; also see Brown et al., this volume). $(\mathrm{E}+) \mathrm{mEq} / \mathrm{L}$ Arrow represents approximate seawater composition.

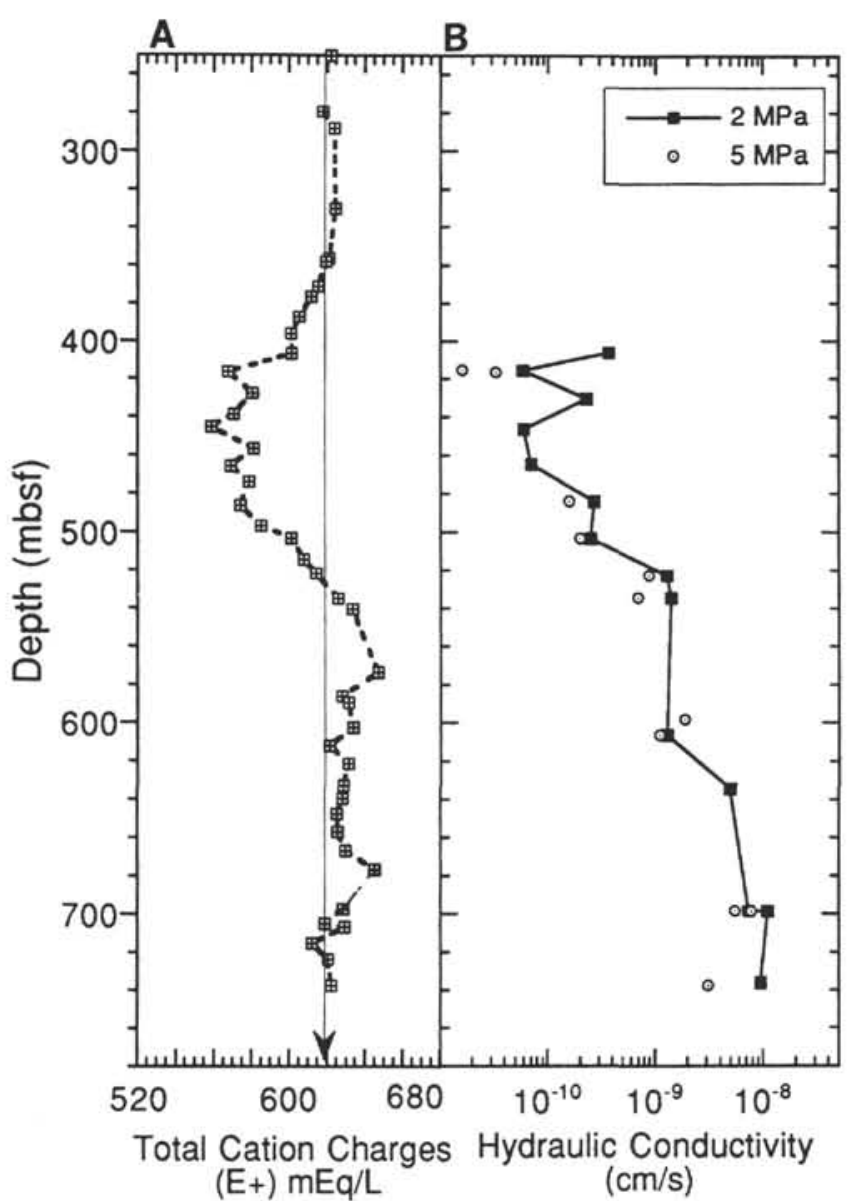

Figure 5. Correlation between the total dissolved cation charge (an indication of the ionic concentration in the fluids) and the measured hydraulic conductivity. Note the spatial correlation of the "freshened zone," between 400 and 500 mbsf, and the region with the lowest hydraulic conductivities. 